\title{
The Historic Sequence of the Celts
}

$\mathrm{D}^{\mathrm{n}}$ R. A. B. SCOTT, in his paper on "The Historic Sequence of Peoples, Culture and Characteristics in Scotland, 400 B.C.-A.D. 950", read before Section H (Anthropology) of the British Association meeting at Aberdeen, began by a reference to the two lines of approach into western Europe : (1) up the Danube Valley, (2) along the course of the Save, and thence into the valley of the Po. Between 1200 and 1000 B.c. a division of the Celts, moving westward, was on the Wallachian and Pannonian plains. The Celts moved as colonists, with families, slaves, workers and cattle, escorted by the military caste. The Celts from the Danube stream produced the descendants who first entered Britain as a $\boldsymbol{P}$-preserving folk. The other stream made contact with Greek peoples, Illyrians, Ligyes (Ligurians), Italic peoples. They met non-Celtic neighbours who pronounced Indo-European $Q u$ in the throat as well as others who articulated it from the lips as $P$.

Reservoirs of Celtic humanity were formed en route, in the Hercynian area, the Isar region, and about the Lakes of Constance and Neuchâtel. These, in turn, spilled out their surplus populations. Long after Gaul had been occupied, groups returned east over the routes of their ancestors such as the Tectosagians, the Tolistoboians (279 B.C.), and certain others who settled in Western Germany. In 600 B.c., the Celts were on the Atlantic sea-board of France. Before 500 B.c. they were on the Atlantic shore of Spain. The descendants of the Danubian stream of Celts were crossing into the British Isles about 800 B.c., and spreading over the land. The tribal names on both sides of the English Channel show that, for a time, the chief Celtic ferry was at the Straits of Dover.

The first, main inflow into Britain, by the Straits about 800 B.c., were Belgæ, Dovonians, and Brigantes. The latter included Manapioi, the ferrymen of the venture. The Belgæ concentrated round Venta Belgarum (Winchester). The Damnonioi (Devonians) were pastoral folk. They and the Belgæ penetrated to Ireland and became known there as Fir Domnann and Fir Bolg. Smaller groups of both, from the English section, spread into Scotland. The Brigantes were cultivators, pastoralists and fort-builders. The Briga of York was their centre, and they were the most powerful tribe in Britain. All these Celts possessed their own military castes. Ganganioi, Brigantes and Manapians were penetrating Ireland between 600 B.c. and 400 B.c. - nearer the former date than the latter.

About 400 B.c., Gaels, according to themselves, arrived in Ireland from the Iberian Peninsula. They secured a footing in parts not occupied by the IroBritish Celts-part of Cork, Kerry and Donegal. They pronounced $Q u$ in their throats as $C$. They aimed at control and tribute. Not until their thirteenth generation did they acquire a measure of power. They were a well-armed minority, organised on a military basis; and they exerted themsielves to secure control of the high-kingship.

About 350 в.c. a small section of Iro-British Celts issued from Ireland to secure a footing in Scotland. The Gaels called these people Cruithne, their designation for all people of Brito-Celtic stock in Ireland. The section that emigrated from the Boyne were warrior-groups, 300 in all; and they were fort. builders. They occupied parts of Man, Rathlin, Islay, Tiree and certain islands in Orkney and Shetland. They were energetic seafarers.

Dr. Scott reviewed the evidence in Pytheas, Julius Cæsar, the "Historia Brittonum", and Ptolemy's "Geographike", pointing to the all-Brittonic outspread "from Totness (Devon) to Burra Head (Shetland)". He then dealt with the transportations of Britons into Scotland by the Romans in A.D. 138 and 182 ; the consequent alterations in tribal names ; and the effect of the counter-migration, more than two hundred years later, under Cunedag, and the creation of the Cymry.

According to Dr. Scott, Eumenius evolved the nickname 'Picts', and applied it to the 'unsubmitted' Britons of Stirling and Perth shires who gave Constantius trouble, and endangered his prospects. He observed that 'Picts' became a literary convention among Latin-writing chroniclers for all 'unsubmitted' Britons, and was used by scribes through medieval times into the modern period.

Dr. Scott showed that the military effect of Cunedag's march from the Forth to North Wales was to turn the left flank of the Romans and to accelerate their retreat. The political effect was that Gwynedd (North Wales) was recreated. The linguistic effect was that the dialect of Celtic ceased to be Brythoneg and became Cymraeg. The domestic effect was that the North Britons came among the imperialised Britons as 'co-workers', hence their designation 'Cymry'.

The third contingent of Celtic incomers to Northern Britain was a body of Dalriads from Antrim who called themselves the 'Clan Erc'. They were not Gaels, but were politically allied to them, and tributary to them. They entered Argyll about 500 A.D. They were a small body, well-armed and organised. Their aim was to impose themselves as a ruling caste on the British Epidioi of Argyll. At their best, the total strength of the Dalriads was 1,410 houses, and an armed muster of 1,500 men. These are the possessions and military strength on which the Gaelic fabulists base the 'Kings of Alba'; the 'Conquest' of Northern Britain; and other inventions of the medieval Gaelic clergy.

The 'Scots' (Irish) who assisted the Northern Rritons against the Romans were the Iro-British allies of the latter from Ulster. Dr. Scott reviewed the political expansion of the Gaels and their ruling caste, and showed how impossible it was, in the then political position, for the Gaels to operate in midBritain. He reminded the audience that the Gaels scarcely influenced Scotland until the early Middle Ages through their clergy or the Dalriads : and that after A.D. 736-741 Dalriad power was broken by Angus MacFergus I. For 160 years the MacAlpin ruling caste subjected the central area of Scotland to an administration of destruction. In A.D. 1005, Malcolm II, son of an Iro-British woman of Leinster, broke away from Gaelic methods; and, with the aid of his friend Crinan, began a constructive and unifying policy.

Dr. Scott concluded by pointing out that the first great monastic schools and ehurches were all founded by men of British or Iro-British blood. 